Journal of Al Azhar University Engineering Sector

Vol. 13, No. 47, April 2018, 498- 513

\title{
LOW-0INCOME POST-OCCUPANCY EVALUATION OF HAIL REGION'S AL-GHAZALAH HOUSING DEVELOPMENT COMPLEX
}

\author{
Ahmed Osman Ibrahim ${ }^{1}$ and Yahya Nasser Alfraidi ${ }^{2}$ \\ ${ }^{1}$ Quality Coordinator, College of Engineering, Architectural Engineering Department, University \\ of Hail, Hail, Region of Hail, Saudi Arabia. \\ ${ }^{2}$ Head of Department, College of Engineering, Architectural Engineering Department, University \\ of Hail, Hail, Region of Hail, Saudi Arabia.
}

\begin{abstract}
In Saudi Arabia, housing projects for the low-income group supported by different government policies as that of the Ministry of Planning and Economy. The post-occupancy evaluation (POE) method is a tool used to assess the functional, social, and technical satisfaction derived by residents from the housing project. The objectives of this study in Saudi Arabia are to investigate the POE process and its applicability, raise awareness of users' rights and needs and offer recommendations for low income housing strategy based on the POE method. The research adopted a quantitative approach using sample survey interview. The survey design based on the POE process. The questionnaires distributed to the residents of the Al-Ghazalah Development Housing Complex to evaluate the three aspects of building performance the functional, social and technical. A feedback from the residents collated and analyzed to reach to conclusion and recommendations.
\end{abstract}

\section{Keywords : Low-income housing development, Housing Types, The post-occupancy evaluation (POE) method}

\section{3-Introduction}

Housing demand is one of the most important issues and challenges that face developing and developed countries, Astnpola, A. (1995). These countries have tried to solve their housing demands with different policies. Some policies and proposals have met the needs of different levels of society. One of these economic classes called the low-income group that encompass some Saudi Arabian people with low annual income. To address the issue on housing income, the government tried to establish residential complexes, an introductory concept and still under trial. This paper will focus on low income housing post occupancy evaluation as the main issue. The housing policy assessed using the post-occupancy evaluation method (POE). However, before investigating the Saudi Arabian policy, it is important to investigate the different international policies for low-income housing.

Low-income housing development are normally houses that are affordable to Median household income. A housing development is a structured real estate development of residential buildings. It is the most significant economic issue for many developed and developing countries. Ggenerally, housing development are often areas of high-density, low-impact residences of single family detached homes, and often allow for separate ownership of each housing units, for example through subdivision. A housing development often erected on a tract of land by one builder and controlled by one management. There are several different housing types. All of which housing developers can choose to develop. They can range from Single Detached, Duplex, Triplex, Multiplex or Big House, Side Attached, Stacked Row house, Small Apartment, Low-rise Apartment, Mid-rise Apartment, Apartment over Commercial, High-Rise Apartment and Public housing. Each of the different housing types will have their distinctive characteristics, density ranges, number of units, and floors. Certain cities will have restrictions on types of developments, Bachman, Leonard R. (2008). 


\section{3-1 Housing Types}

According to Wordometers, current population of Saudi Arabia is 33,150,617 as of Sunday, November 5, 2017, based on the latest United Nations estimates anticipated to reach $45,056,349$ by the year 2050 . The total land area is $2,149,690 \mathrm{Km} 2$ (830,000 sq. miles) $78.4 \%$ of the population is urban. In the past few years, the government of Saudi Arabia has provided houses to needy families and a few housing projects built in different parts of the country. AlGhazzaleh Housing Project of Hail town is one of such projects, provided for low-income people. Conducting studies about low-income housing and implementing policies are important to provide alternatives for economic solutions and define appropriate housing for millions of low-income population around the world. Various government and non-government organizations have played an active role in the development of housing models for low income groups and some have succeeded in providing them appropriate housing. In the past years, the government of Saudi Arabia has provided houses to needy families and a few housing projects built in different parts of the country. This research shall focus on the Al-Ghazalah project as a case study. The housing project will be evaluated using POE (post-occupancy evaluation) done by distributing a questionnaire to the residents of the AlGhazalah project to identify merits and demerits of these houses. Al-Ghazalah Housing Project located in the region of Hail, City of Hail is one of the many low-income housing projects that the government of Saudi Arabia has built in 2007. It has 254 housing units, two schools, two mosques, a health center and a community center designed to a standard prototype including three bedrooms, a living room, a kitchen, a guest room and two bathrooms.

\section{3-2 Post-Occupancy Evaluation (POE)}

There has been a fast-paced build-up of residential territories in Saudi Arabia. To mitigate abusive practices and low quality, several means introduced and one of them is the post occupancy evaluation (POE). This method will show gaps between the designer and end-user of the homes. It will allow control of supply and demand in the construction process since the formation of the final product lacks the participation of end-user in the planning or design processes. The lack of knowledge of the end-user can be problem for planners and designers, Bordass, B. (2003).

POE is the process of obtaining feedback on a building's performance in use. It is as well an architectural process for improving buildings' fitness for purpose. It produces recommendations for building solutions and ways of using buildings to enhance productivity and wellbeing. The recommendations based on stakeholders' testable observations about buildings` support and frustration of their work and wellbeing. The value of POE increasingly recognized, and it is becoming mandatory on many public projects. POE is valuable in all construction sectors, especially healthcare, education, offices, commercial and housing, where poor building performance will impact on running costs, occupant well-being and business efficiency. Post-Occupancy Evaluation highlights any immediate teething problems that can be addressed and solved, identify any gaps in communication and understanding that impact on the building operation, pprovides lessons that can be used to improve design and procurement on future projects, acts as a benchmarking aid to compare across projects and over time, Bordass, B. \&Leamon, A. (2005). Many buildings do not perform as planned - in some cases, this can affect running costs, staff and client satisfaction and performance, health, safety and comfort. For repeat construction clients, learning from, correcting past mistakes in design, and commissioning of buildings can be extremely cost-effective and greatly improve workplace productivity, British Council for Offices (2007).

The emergence of many of occupant problems resulting from mass housing projects that have been designed without taking into account the needs and desires of the end-user of a place, Robinson, Charles W, (2005). This leads to an urgent need for an acceptable method to determine the impact of projects on the users in consideration to location, social, technical and economic dimensions of the urban environment. POE is a process of rating a building in a systematic and rigorous manner after it was been occupied period, Preiser, W.F.E. (2001). On the other hand, Preiser, W. F. E. (1995) defined POE as "any and all activities that originate out of an interest in learning how a building performs once it is built, including if and how well it has met expectations,".

It was also further defined as "a systematic study of buildings in use to provide architects with information about the performance of their designs and building owners and users with guidelines to achieve the best out of what they already have," by the RIBA Research Steering Group, RIBA, 1991. Preiser, W.F.E et al (1988). From the point of view of a facility manager, defined POE as "a diagnostic tool and system, which allows facility managers to identify and evaluate critical aspects of building performance systematically".

POE implemented by a range of building industry professionals and by the client or building owners. POEs employ a variety of methods aimed at finding out how well a structure met the needs of its users and satisfies the goals for which it was designed, Bordass Leaman \&Ruyssevelt (2001). POE aimed at improving the building and its management with all stakeholders ranging from clients, project managers, designers, to builders, Bordass, B. (2003). POE methods have evolved over the years to provide successful collection of data for all stakeholders in the construction project. It was suggested that POE require a long-term commitment to data collection, analysis, and 
information sharing, Bordass. This is with the goal of improving new projects while avoiding problems in future ones.

\section{Housing Policies of Low Income Groups in Kingdom of Saudi Arabia}

In Saudi Arabia, the high price of land prevents many families to afford land to build their homes, Gandil, M. M. (1996). This attributes to the decline in the number of housing units provided by some government agencies and the lack of funds available to keep pace with the demand for housing loans, Al-Harigi, F. (2004). Development plans consider raising the standard of living and improving the quality of life for citizens as a priority (Ministry of Planning and Economy in KSA, 2011). It is imperative to address reduction of unemployment and tackling poverty. Plans include stimulation of private, domestic and foreign entities towards less developed regions, taking into account the population as laid down by the Cooperation Council for the Arab Gulf States (GCC), and the Millennium Development Goals adopted by the United Nations. As mentioned, the low-cost housing policies in Saudi Arabia investigated via the post-occupancy evaluation method (POE).

\section{4-1 Housing in the Hail Region}

The need for housing in the region of Hail, considered as an exemplar of housing needs in Saudi Arabia. Khaleej Times (2009) indicated that the percentage of housing villas in Hail is about $22.1 \%$ of the total housing while affordable housing is about $48.05 \%$. A large part of the Hail's housing accommodation is not good. Figure (1) shows that "floor in a villa or house" constitutes only about $4.35 \%$, while the apartment is $6.79 \%$. This means that the two types of housing floors and flats are that much available. Tents consist of $12.55 \%$ meaning that housing of this kind still in use in the Hail region. Straw houses are at around 0.28\%, Khaleej Times (2009).

This shows that the percentage of low-quality housing, which includes affordable housing, straw housing, metal housing and tents, is about $66.76 \%$. This constitutes more than $2 / 3 \mathrm{rd}$ of the total housing in Hail, which means that there is the need for more housing in the Hail region, Abdullah, A. (2009).

Referring to the percentage of housing percentage above, the conclusion is that the issue of housing for low-income people raised in terms of the needs of an increasing number of low-income families in the world, Watson, M. et al (2001). The policies for low-income housing have emerged in both developed countries and developing countries. Saudi Arabia being one of the developing countries has implemented such a policy in its development plans in order

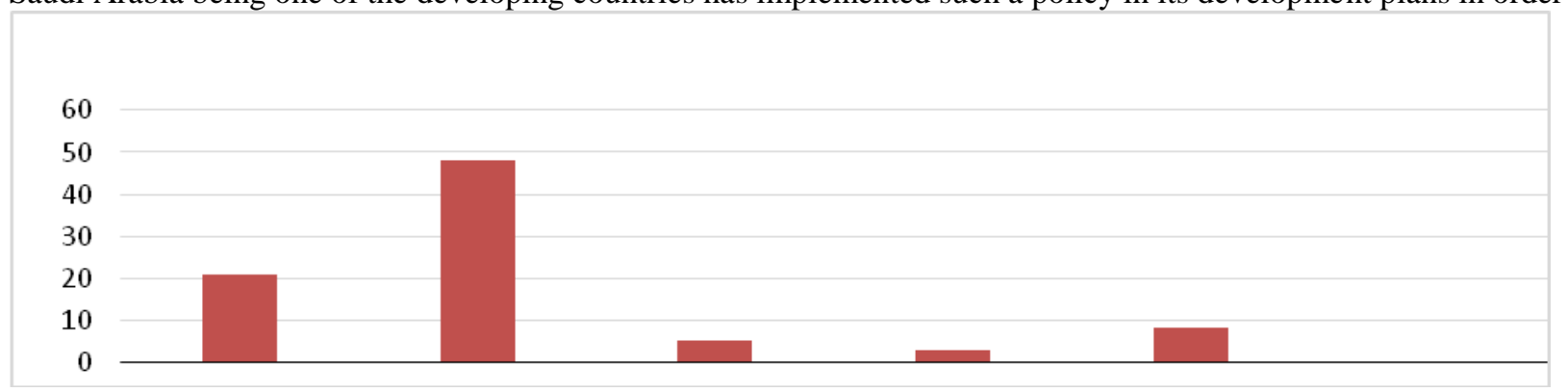

Figure (1) Percentage of the Type of housing in Hail region, Khaleej Times (2009).

to help people suffering from high prices of construction and those who have no any source of income to build houses. Hail is one of the areas in which the issue of low-income housing raised, therefore, considered in this research to start by gathering the opinions and feelings of the current occupants through the POE method. This will determine the strengths and weaknesses of the design of the housing units in order to enhance the strengths and address weaknesses in the ongoing housing projects designs. On the other hand, it will highlight on the weaknesses in the new housing projects in terms of issues related to the design of the units.

\section{5- The Al-Ghazalah Development Housing Complex}

Low-income housing is a main issue for many developed and developing countries. Conducting studies about lowincome housing and implementing policies are important to provide alternatives for economic solutions and define appropriate housing for millions of low-income population around the world. Various government and nongovernment organizations played an active role in the development of housing models for low-income groups and some succeeded in providing them appropriate housing, Bryman, A. (2008). 
In the past years, the government of Saudi Arabia has provided houses to needy families and a few housing projects built in different parts of the country. Al-Ghazalah of Hail is one such projects, provided for low-income people. This research focused on the Al-Ghazalah project as a case study. The housing project evaluated using POE (postoccupancy evaluation). The evaluation made by distributing questionnaires to the residents of the Al-Ghazalah project to identify the advantages and disadvantages of their houses. The continent of Asia with the location of K.S.A, the map of K.S.A, the location of the region of Hail in the K.S.A, Al-Ghazalah province location in the region of Hail and the Al-Ghazalah housing Complex with housing units and the public services of the housing units, figure (2), (3), (4), (5) and (6).

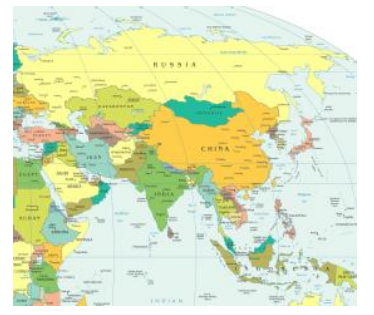

Figure (2) the Continent of Asia with the location of

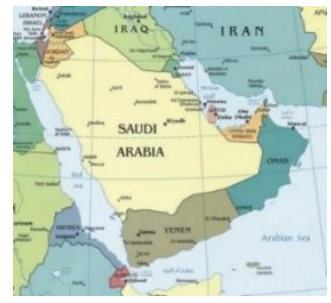

Figure (3) the map of K.S.A

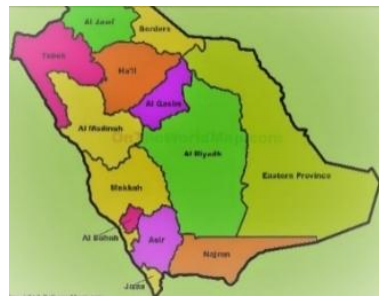

Figure (4) the location of the region of Hail in the K.S.A

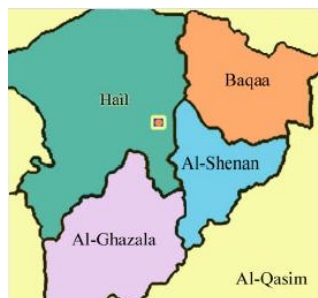

Figure (5) Al-Ghazalah province location in the region of Hail

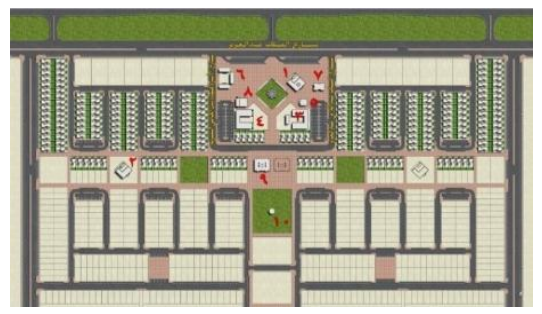

Figure (6) Al-Ghazalah housing Complex with housing units and the public services of the housing units

Al-Ghazalah governate is one of the many low-income housing complexes that the government of Saudi Arabia built in 2007. This huge project is a type of low-income housing or popular housing so much considered in the Kingdom of Saudi Arabia. It has 254 housing units, Educational, commercial and investment elements, centers, health and social services, training and rehabilitation center and administrative center more precisely two schools, two mosques, a health center and a community center.

The various main buildings components of the complex are as follows; the number 1 indicates King Abdulaziz Mosque, 2 indicates King Abdullah Bin Abdulaziz mosque, 3 indicates King Abdulaziz Primary School for Boys, 4 indicates Princess Fahdah Bint Al-Asi ASherem Primary Health Care, 5 indicates The Training and Rehabilitation Center. The number 7 indicates the Housing Complex Administration Building, 8 indicates the Social Center, 9 indicates the Housing Apartment Complex and 10 indicates the overhead reservoir, all together form the entire AlGhazalah development housing Complex. The Housing Development Project in Al-Ghazalah Governorate of Hail, adopted by King Abdullah Bin Abdulaziz Foundation for his parents for development housing. The housing units considered one of the major projects in the implementation of charitable work in Hail to the size and breadth of the housing units and the number of housing units at a cost of 60 million riyals. The main reason for the selection of the governate of Al-Ghazalah for the housing units as it serves more than 35 villages. The choice of its location amongst these villages is due to the abandonment of the subsidiary villages, which population suffers from need, poverty as most of its destitute poor live in tents in the desert and abandoned houses. Inhabitants of these villages considered beneficiaries of this project that covers a zone of $100 \mathrm{~km}$ diameter, therefore, not limited only to Al-Ghazalah governate. The development housing project in Al-Ghazalah is a modern huge complex development with integrated services officially handed over to its owners on 25/05/2007. The project consisting of 258 housing units benefiting 1778 citizens. The area of the whole complex is 396 square meters. The authorities handed over the fully equipped housing units with their necessary services, the documents and their keys to their owners, Bahmam, A. \& Bahbayl, M. (2007). 


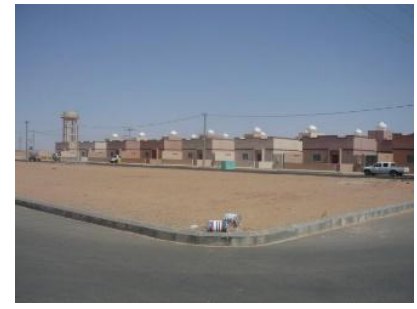

\section{5-1 The current situation of the project}

Figure (5) the housing unit's ground floor plan

The housing units are modern and economical, and accept vertical and horizontal expansion according to the requirements of the future resident, in addition to its compatibility with the surrounding environmental and climatic conditions as well as the suitability with the customs and traditions of the Saudi family. The housing units includes all basic services such as water, electricity, telephone and sewage networks, road networks, lighting and paving. The housing units will also provide a wide range of development programs, including education, training and opportunities for lending and work. The housing units are part of a plan to build 2522 houses in the Kingdom of Saudi Arabia at a cost of 500 million riyals to cover all regions of the Kingdom.

The housing units designed to a standard prototype including three bedrooms, a living room, a kitchen, a guest room and two bathrooms in the ground floor plan shown below, picture (5).

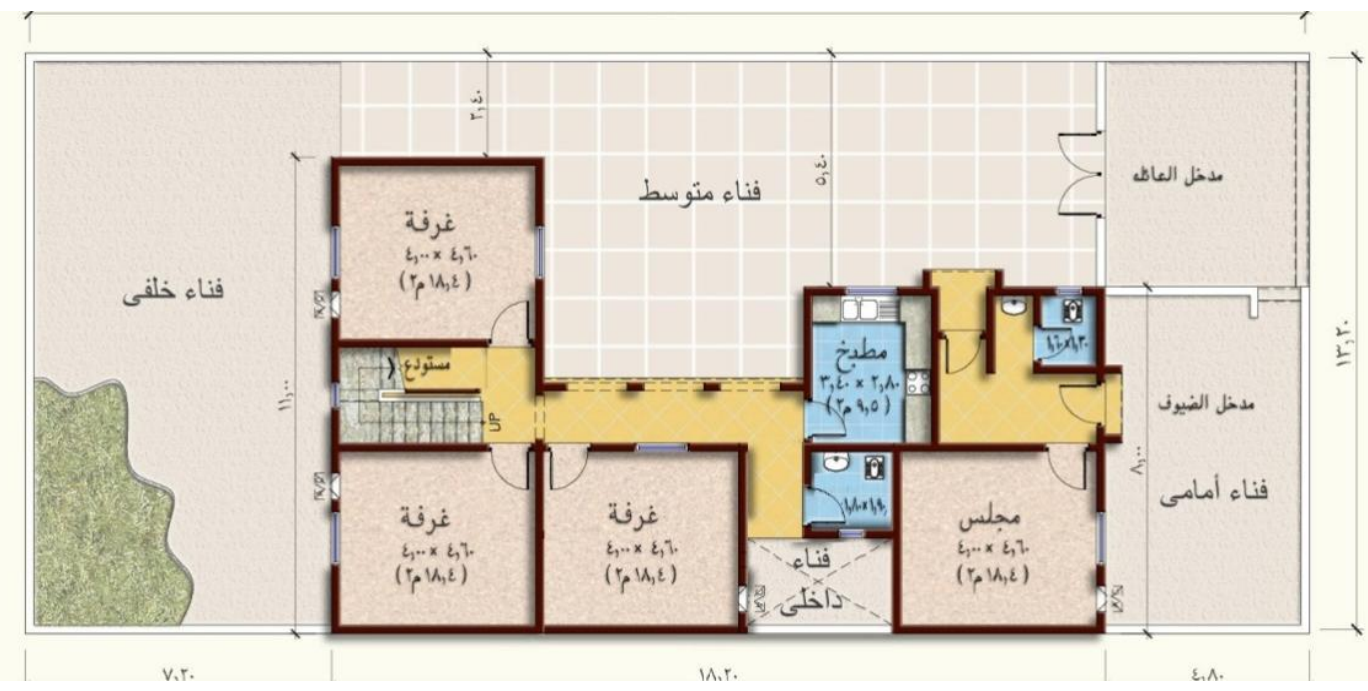

Photos of the current situation provided to assist in analysing the functional, social and technical aspects of each housing unit. An over view of some components of the public services units shown to give a general idea of how distributed are such units in the complex and how related they are to the housing units.

The Housing Development Complex as in 2007 where one of the mosques, a road with parking areas in between housing units, a group of housing units and a single housing unit shown in the pictures (1), (2), (3) and (4).

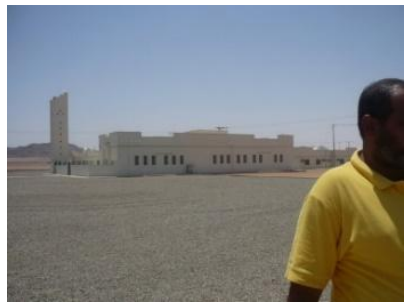

Picture (1) one of the mosques

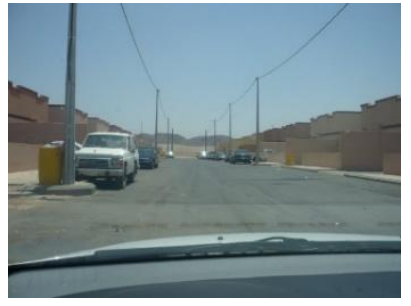

Picture (2) a road with parking areas in between housing units

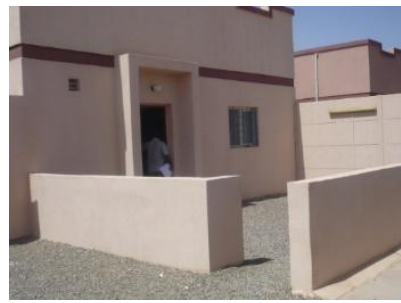

Picture (4) a single house unit 


\section{5-2 The Al-Ghazalah complex post-occupancy evaluation main three aspects}

The research provides a scope in-depth about the current situation of the complex. Photos of the current situation provided as well as observations and comments based on discussions with some residents taking in consideration. Questionnaires analysis employed to have a comprehensive post-occupancy evaluation of the complex.

\section{5-2-1 The functional aspect of the complex Building materials:}

The materials used in these buildings are of poor quality as so many buildings suffer from cracks in the different parts of the structures, the cracks and collapse of one of the housing units front walls vividly shows this, picture (5).

- Water supply system:

There is a shortage in water supply. This shortage led residents to buy water from trader trucks and some of them had to dig a well inside their own house, pictures (6). Despite the availability of water reservoirs on top of buildings, residents still suffer from water shortage, pictures (7)

- Drainage system:

There is leakage in the sewage system causing pipes blockage in the drainage system, pictures (9). Sewage covers are open or easy to open, which may harm the residents or their kids, as they are scared that their kids fall in sewage holes that could easily open, pictures (8).

- Maintenance:

There is a lack of proper maintenance as many structures and facilities damaged and haphazardly maintained by unexperienced local residents, pictures (9).

\section{Buildings design:}

A number of residents took it upon themselves to build and change the design of the house and most of them changed the front of the house, built a reception room for guests and changed the yard into a living room as shown in pictures (10).

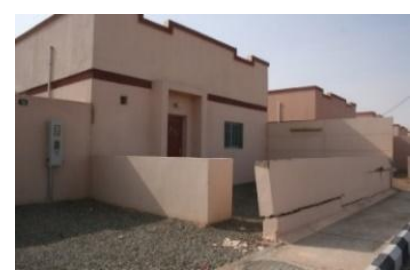

Picture (5) the cracks and collapse of one of the housing units

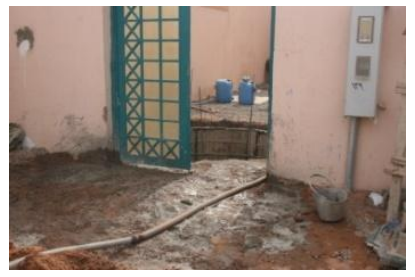

Picture (9) lack of maintenance

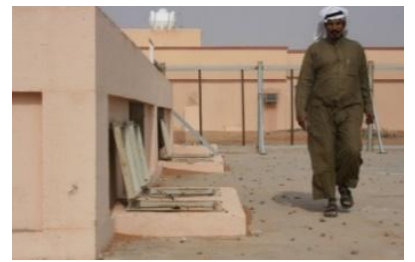

Picture (6) a well dug inside a house units front walls

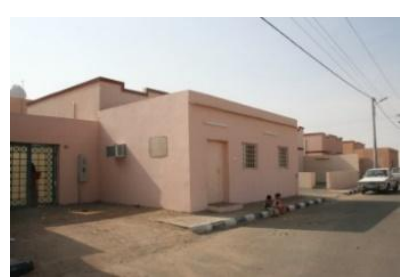

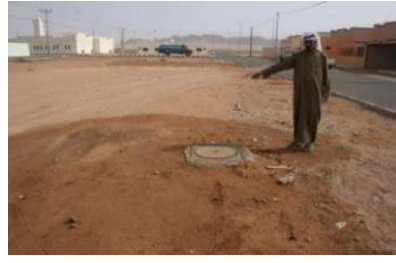

Picture (7) reservoirs on top of buildings

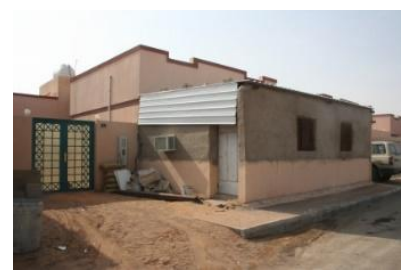

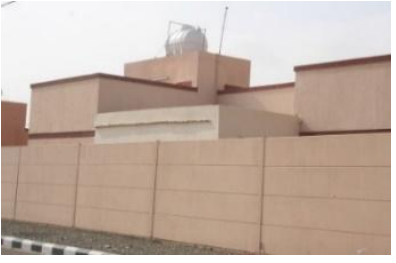

Picture (8) sewage holes that could easily open

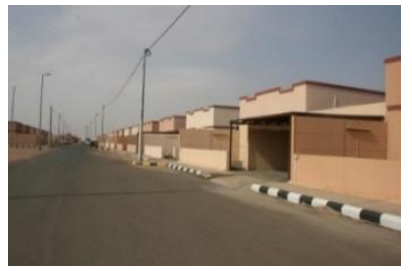

Picture (10) structures and facilities damaged and haphazardly maintained

\section{6- Questionnaire Design}

The research used self-employed questionnaires in gathering data because of three reasons; the issue of housing is personal and subjected to a fear response from the respondents, questionnaire is less expensive and more convenient for the research and lastly to present the residents participation in post-occupancy evaluation, Gray, D. G. (2000). The questionnaire designed based on the post-occupancy evaluation process. A process employed in AlGhazalah low-income housing complex employed to get feedbacks from the residents. The questionnaire combined multiple choices, rating scale and yes or no questions formats in order to easily understood and statistically analyzed. The questionnaire given to the residents was in Arabic language with an English version for the purpose of the research. It has four parts:

Part I that dealt with the profile of the respondents in terms of sex, age, number of years living in the housing unit, number of persons living in the building. Part II that dealt with the function of the housing units. It has three subparts: II a. The respondents were asked to rate the questions objectively depending on their extent of satisfaction. The 
following descriptions used as a scale in determining the level of respondent's satisfaction in the function of the housing unit, Leung, C. C. (2005), table (1):

Table (1) these descriptions used as a scale in determining the level of respondent's satisfaction

\begin{tabular}{|l|l|l|l|l|l|}
\hline To what extent are you satisfied with the: & very dissatisfied & dissatisfied & neutral & satisfied & Very satisfied \\
\hline & & & & & \\
\hline & & & & \\
\hline
\end{tabular}

II $b$. This sub-part is a follow up question dealt with the number of times the respondent's use the housing unit roof per month.

II c. Follow-up questions which used the "yes" or "no" format of questionnaires.

Part III dealt with the social aspect of the housing unit.

III a. The respondents asked to answer the questions by yes or no.

III $b$. The respondents rate the given questions based on their level of satisfaction on the social aspect of the housing unit. Same scale rates and descriptions like on the previous part used.

Part IV dealt with the technical aspect of the housing unit.

IV a. Respondents were asked to rate their level of satisfaction based on the building's technical features. Same rating scale also used.

IV b. The "yes" or "no" format of questionnaire used in this sub-par, figure (7).

This part also asked the respondents to write the three most like and three most dislike about the building.

Figure (6) the "yes" or "no" format of questionnaires

Do you want the result of the survey to be sent to you? Yes

Lastly, the research also asked if the respondents want, the result of the survey sent to them. The question used a "yes" or "no" format.

\section{6-1 Data analysis techniques}

The Statistical Package for Social Sciences (SPSS) used in analyzing the questionnaire questions. It shows the descriptive statistics such as the mean, median, frequency distributions and standard deviation the one sample t-test to test the hypothesis as well as level of significant. In other word, if the P-value is less than 0.050 that means that the relationship is significant, by contrast, if the P-value is more than 0.050 thus the relationship is not significant.

The mean score rating calculated using the formula:

$$
\text { Mean }=\frac{1 \cdot\left(n_{1}\right)+2 \cdot\left(n_{2}\right)+3 \cdot\left(n_{3}\right)+4 \cdot\left(n_{4}\right)+5 \cdot\left(n_{5}\right)}{\left(n_{1}+n_{2}+n_{3}+n_{4}+n_{5}\right)}
$$

Where $\mathrm{n}_{1}, \mathrm{n}_{2}, \mathrm{n}_{3}, \mathrm{n}_{4}, \mathrm{n}_{5}$ mean the total number of residents choosing as 1 to 5 of the rating scale respectively, which 5 represent that the respondent is very satisfied, and 1 that he/she is not satisfied at all. The variability of the results was expressed as standard deviation, which shows how widely disperse a set of measurements about the mean is.

\section{6-2-Questionnaire Findings and Analysis}

Part I: 
$2-$ Age?

Personal factual information

$1-$ Sex:

\begin{tabular}{|cc|c|c|}
\hline \multicolumn{3}{|c|}{ Table 2: Sex of Respondents } \\
\hline & & Frequency & Percent \\
\hline Valid & M & 72 & 80.0 \\
& F & 18 & 20.0 \\
& Total & 90 & 100.0 \\
\hline
\end{tabular}

\begin{tabular}{|cc|c|c|}
\hline \multicolumn{3}{|c|}{ Table 3: Age Range of Respondents } \\
\hline Valid & $20-30$ & Frequency & Valid Percent \\
& 15 & 16.7 \\
& $31-40$ & 34 & 37.8 \\
$41-50$ & 27 & 30.0 \\
$51-60$ & 8 & 8.9 \\
$61-70$ & 6 & 6.7 \\
& Total & 90 & 100.0 \\
\hline
\end{tabular}

Family members socially interacting in hose units analyzed in the tables a above in reference to questionnaires, tables (2), (3), (4), (5) and (6). The inspection of table (4) about the number of family members living in the same unit shows variation, for instance from 90 respondents only 32 answered agreeing with the 2-4 range included the parents, and 44 answered agreeing with the 5-7 range. However, the number of people who are living in the same house, table (2), will be influential in the degree of satisfaction with housing (Fahad, A. 2004); this means if the

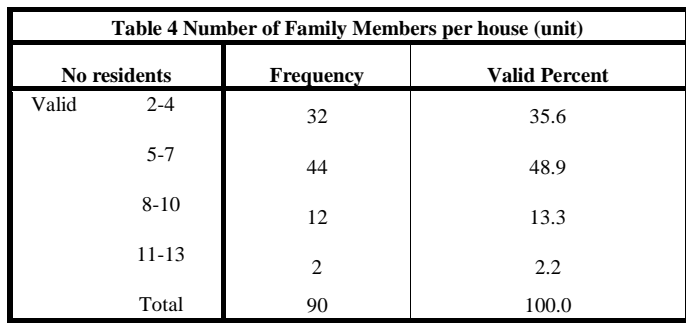

3- How many people are living in this house?

4- How many hours (average) in a day spend in this building?

\begin{tabular}{|cc|c|c|}
\hline \multicolumn{3}{|c|}{ Table 6: Social Relationships. } \\
\hline & & Frequency & Valid Percent \\
\hline Vali & Yes & 61 & 67.8 \\
d & No & 29 & 32.2 \\
& Total & 90 & 100.0 \\
\hline
\end{tabular}

\begin{tabular}{|c|c|c|c|}
\hline \multicolumn{3}{|c|}{ Table 5: Average Time Spent at Home } \\
\hline & & Frequency & Valid Percent \\
\hline \multirow{4}{*}{ Valid } & $5-8$ & 16 & 17.8 \\
& $9-12$ & 23 & 25.6 \\
& $13-16$ & 32 & 35.6 \\
& $17-20$ & 11 & 12.2 \\
& $21-24$ & 8 & 8.9 \\
& Total & 90 & 100.0 \\
& & & \\
\hline
\end{tabular}

5- Are all your family members, your neighbors? relatives or their relationships live together?

number of family is big, the house will not be enough to accommodate all of them, noting that the existing housing units in the complex designed for small family.

As shown in the table (5) 32 (35.55\%) of the total number of respondents spends an average of 13-16 hours per day in the house unit. Followed by $9-12$ with 23 respondents $(25.55 \%)$, and only $8(8.88 \%)$ spends $21-24$ hours a day. The respondents of 13-16 and 17-20 hours range that spend their time in the unit were mostly the housewives with part time jobs or not working at all. While, based on the age range of the respondents, figure (6), the 5-8 and 9-12 range were workers and the 21-24 hours were the old folks who spend most of their time at home.

More than half of the respondents $(67.77 \%)$ revealed that their neighbors are also their relatives, since that neighbors have relationship, that might minimize misunderstandings and disagreements between neighbors, and only 29 $(32.22 \%)$ said that they are not related or don't have any relationship with their neighbors, as shown in table (7). 
Part II -A - function aspect

Table (7) illustrates the respondents' values for each factor about the housing function asked

\begin{tabular}{|c|c|c|c|c|}
\hline \multicolumn{5}{|c|}{ Table 6 Functional Aspect for Each Factor $(\mathrm{N}=90)$} \\
\hline Factors & Mean & Median & S.D & P-Value \\
\hline 1 & 2.610 & 3.000 & 0.920 & .000 \\
\hline 2 & 3.290 & 3.000 & 1.073 & .000 \\
\hline 3 & 2.800 & 3.000 & 0.796 & .000 \\
\hline 4 & 2.840 & 3.000 & 0.923 & .000 \\
\hline 5 & 3.570 & 4.000 & 0.900 & .000 \\
\hline 6 & 3.640 & 4.000 & 1.290 & .000 \\
\hline 7 & 3.400 & 3.000 & 1.261 & .000 \\
\hline 8 & 3.700 & 4.000 & 0.977 & .000 \\
\hline 9 & 2.840 & 3.000 & 0.928 & .000 \\
\hline 10 & 3.460 & 3.000 & 1.133 & .000 \\
\hline 11 & 3.520 & 4.000 & 0.986 & .000 \\
\hline 12 & 3.110 & 3.000 & 1.075 & .000 \\
\hline 13 & 3.400 & 3.000 & 1.261 & .000 \\
\hline 14 & 3.570 & 4.000 & 0.900 & .000 \\
\hline 15 & 3.170 & 3.000 & 1.094 & .000 \\
\hline 16 & 3.210 & 3.000 & 1.137 & .000 \\
\hline 17 & 3.610 & 4.000 & 1.347 & .000 \\
\hline 18 & 3.820 & 4.000 & 0.869 & .000 \\
\hline 19 & 3.210 & 3.000 & 1.137 & .000 \\
\hline 20 & 3.020 & 3.000 & 1.038 & .000 \\
\hline 21 & 3.830 & 4.000 & 0.877 & .000 \\
\hline 22 & 2.390 & 3.000 & 0.803 & .000 \\
\hline 23 & 2.880 & 3.000 & 0.958 & .000 \\
\hline 24 & 3.660 & 4.000 & 1.291 & .000 \\
\hline 25 & 3.300 & 4.000 & 1.213 & .000 \\
\hline 26 & 2.300 & 3.000 & 0.771 & .000 \\
\hline 27 & 2.580 & 3.000 & 0.899 & .000 \\
\hline 28 & 2.840 & 4.000 & 0.923 & .000 \\
\hline 29 & 3.400 & 3.000 & 1.364 & .000 \\
\hline 30 & 3.010 & 3.000 & 1.033 & .000 \\
\hline 31 & 3.810 & 4.000 & 0.873 & .000 \\
\hline 32 & 3.300 & 3.000 & 1.213 & .000 \\
\hline 33 & 2.500 & 2.000 & 0.824 & .000 \\
\hline 34 & 2.770 & 3.000 & 0.887 & .000 \\
\hline 35 & 2.310 & 3.000 & 1.242 & .000 \\
\hline
\end{tabular}

Out of inspection table, these two bellow chosen as exemplars out of many various important factors:

- Factor 1 (House Areas): the respondents are not satisfied enough with the house areas, the mean is 2.610, however, the median is 3.000, which judged as naturally satisfied with house areas.

- Factor 2 (Space between neighbors): this factor discussing whether the space between neighbors is enough for privacy for instance, the mean is 3.290, which mean that the residents requests more space; that could also be noticed by the median value of 3.000 .

Part II -B - function aspect

- How many times do you use the roof per a month?

\begin{tabular}{|ll|c|c|}
\hline \multicolumn{4}{|c|}{ Table 8: Roof in Use (Times). } \\
\hline & & Frequency & Valid Percent \\
\hline Valid & More & 29 & 32.2 \\
& $17-14$ & 27 & 30.0 \\
& $13-10$ & 18 & 20.0 \\
$9-6$ & 9 & 10.0 \\
& $5-2$ & 7 & 7.8 \\
& Total & 90 & 100.0 \\
\hline
\end{tabular}

\begin{tabular}{|cc|c|c|}
\hline \multicolumn{3}{|c|}{ Table 9 Changes of House. } \\
\hline & & Frequency & $\begin{array}{c}\text { Valid } \\
\text { Percent }\end{array}$ \\
\hline Valid & Yes & 29 & 32.2 \\
& No & 61 & 67.8 \\
& Total & 90 & 100.0 \\
\hline
\end{tabular}

\begin{tabular}{|c|c|c|c|}
\hline \multicolumn{4}{|c|}{ Table 10: Add More Space. } \\
\hline & & $\begin{array}{l}\text { Frequency } \\
\end{array}$ & Valid Percent \\
\hline \multirow[t]{3}{*}{ Valid } & Yes & 72 & 80.0 \\
\hline & No & 18 & 20.0 \\
\hline & Total & 90 & 100.0 \\
\hline
\end{tabular}

- Do you think that you will add more spaces to the house?

Did you or you think that you are going to make changes in the house?

Tables (8), (9), and (10) above show change of house by adding more space as by using more roof spaces

Table (8) shows that the highest number the roofs used per month was more than 17 times (32.22\%) and the lowest was ranges from number $2-5$ with7 respondents $(7.77 \%)$. Table (9) shows the percentage of those who are going to make changes in the house and figure (10) indicates the percentage of those who think of adding more spaces to their houses. Tables (8), (9), and (10) above show change of house by adding more space as by using more roof spaces.

Part II - C - function aspect

It is reflected from the table that majority of the respondents $(67.77 \%)$ do not want to make changes or renovation in the house. While $80 \%$ noted that, they will add more spaces to the house. 
Table 11 where respondents believe that the housing function aspect is not enough satisfied their minimum requirements

\begin{tabular}{|l|l|l|l|l|}
\hline \multicolumn{5}{|l|}{ Table 10: Functional Aspect Statistics (N=90) } \\
\hline
\end{tabular}

Table (11) showing how the housing function aspect is not enough to satisfy respondents' minimum requirements. In particular, this obviously notified by the mean value of 3.022 and median 3.190. In other words, they are requesting for more attention for their housing requirements and minimum services. The p-values were less than 0.050 (.000), thus the hypothesis that the users of residents are not satisfied with the functional aspect of residents is accepted. Figure (7) shows the satisfaction mean with the different factors of functional aspect.

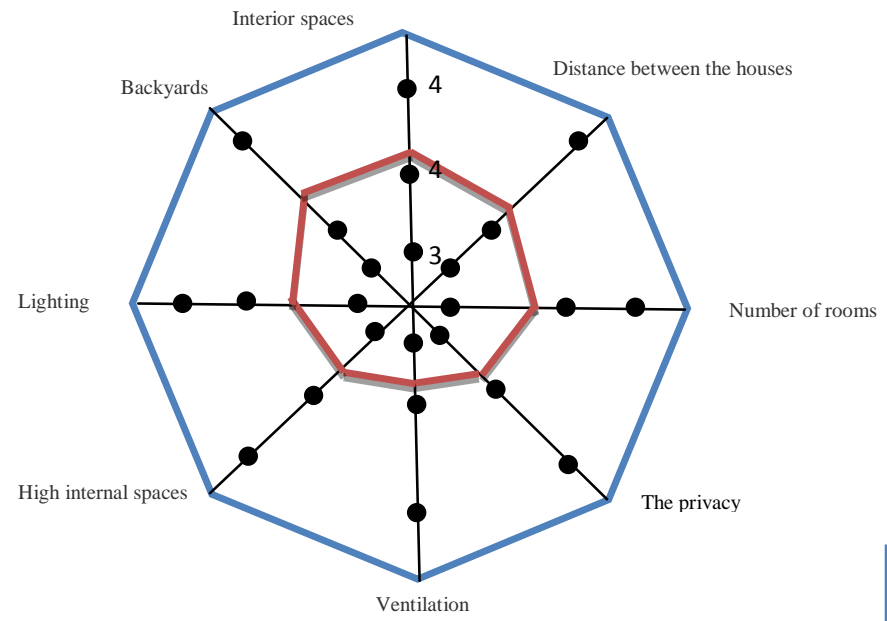

The desired profile

The current situation

Part III -A- Social aspect.

Figure (7) the satisfaction mean with the different factors of functional aspect

Table 12: Social Aspect (Yes and No Questions)

\begin{tabular}{|c|c|c|}
\hline Variables & Frequency & Valid Percent \\
\hline $\begin{array}{l}\text { Do you support the difference in the external style between housing units? } \\
\text { Yes } \\
\text { No }\end{array}$ & $\begin{array}{l}45 \\
45 \\
\end{array}$ & $\begin{array}{l}50 \\
50 \\
\end{array}$ \\
\hline Total & 90 & 100 \\
\hline \multirow{6}{*}{$\begin{array}{l}\text { Do you receive guests at the house? } \\
\text { if your choice is yes } \\
\text { Yes } \\
\text { No } \\
\text { if your choice is yes: } \\
\text { A - How many times per month? } \\
1-10 \\
11-20 \\
21-30 \\
\text { B - Do you receive men and women at the same time? } \\
\text { Yes } \\
\text { No }\end{array}$} & $\begin{array}{r}54 \\
36 \\
\end{array}$ & $\begin{array}{l}60 \\
40 \\
\end{array}$ \\
\hline & 90 & 100 \\
\hline & $\begin{array}{c}8 \\
27 \\
19\end{array}$ & $\begin{array}{c}14.81 \\
50 \\
35.18\end{array}$ \\
\hline & 54 & 100 \\
\hline & $\begin{array}{l}37 \\
17 \\
\end{array}$ & $\begin{array}{r}68.52 \\
31.48 \\
\end{array}$ \\
\hline & 54 & 100 \\
\hline $\begin{array}{l}\text { Is the uniqueness of the external style important to you? } \\
\text { Yes } \\
\text { No }\end{array}$ & $\begin{array}{l}27 \\
63\end{array}$ & $\begin{array}{l}30 \\
70\end{array}$ \\
\hline Total & 90 & 100 \\
\hline $\begin{array}{l}\text { Will you change the external style? } \\
\text { Yes } \\
\text { No }\end{array}$ & $\begin{array}{l}36 \\
54\end{array}$ & $\begin{array}{l}40 \\
60\end{array}$ \\
\hline Total & 90 & 100 \\
\hline $\begin{array}{l}\text { Do you suffer from any harassment inside the residential complex? } \\
\text { Yes } \\
\text { No }\end{array}$ & $\begin{array}{l}54 \\
36 \\
\end{array}$ & $\begin{array}{l}60 \\
40 \\
\end{array}$ \\
\hline Total & 90 & 100 \\
\hline $\begin{array}{l}\text { Do you participate in the programs conducted in your neighborhood? } \\
\text { Yes } \\
\text { No }\end{array}$ & $\begin{array}{l}38 \\
52\end{array}$ & $\begin{array}{l}42.22 \\
57.77 \\
\end{array}$ \\
\hline Total & 90 & 100 \\
\hline
\end{tabular}


From Table (12) above, there are equal numbers of respondents as $50 \%$ want to support the difference in the external style between housing units and the other 50\% do not want to do so. Taking into consideration the residents interest in the reception of guests at home, more than half of the respondents equal to $60 \%$ answered "yes". On the follow up question, only 54 respondents equal to $60 \%$ were qualified to participate in responding to the questionnaire. 27 respondents or $50 \%$ of 54 answered that they received guests, which ranges from 11-20 per month. On the other hand, 37 or $68.52 \%$ received male and female guests at the same time. From the statistics, the uniqueness of the external style of the building block is important to the respondents; even though $70 \%$ emphasized that, it is not important. About $60 \%$ not interested in changing the external style of the building block. Based on the survey $60 \%$ admitted that they suffer from harassment inside the residential complex. Findings also show that $57.77 \%$ of the respondents do not participate in the programs conducted in their neighborhood.

Part III -B- Social aspect

Out of inspection table, these two bellow chosen as exemplars out of many various important factors:

- Factor 1 (Activities with neighborhood): this factor is discussing the social activities in the residential complex. The mean was 4.410, whereas the median 5.000 with high satisfied respondents. This expected due to the Arabic culture on which the social life depends, as the fact that people are likely to interrupt and communicate with each other's matters Fahad, A. (1982).

- Factor 2 (Residential entertainment): this factor discussing the entertainment buildings or zones inside the residential, for instance, parks and kids playing zones. However, the respondents are not satisfied enough with the entertainment services provided with mean 2.900. Figure (8) shows the satisfaction mean with the different factors of social aspect.

Table (13) shows the social aspect statistics for each factor whereas table (14) shows the table social aspect for each factor as table (15) shows the table social aspect for each factor based on the respondents dissatisfaction with the social aspect of the residents. The mean was 3.278, median 3.000 and the P-value of .000 (less than 0.050). Thus, the hypothesis that the residents are not satisfied with the social aspects of residents is accepted.

Table 13 shows the social aspect statistics

Activities

\begin{tabular}{|c|c|c|c|c|}
\hline \multicolumn{5}{|c|}{ Table 13 Social Aspect Statistics (N = 90) } \\
\hline & Mean & Median & S.D & P-Value \\
\hline Social Aspect & 3.278 & 3.000 & 0.647 & .000 \\
\hline
\end{tabular}

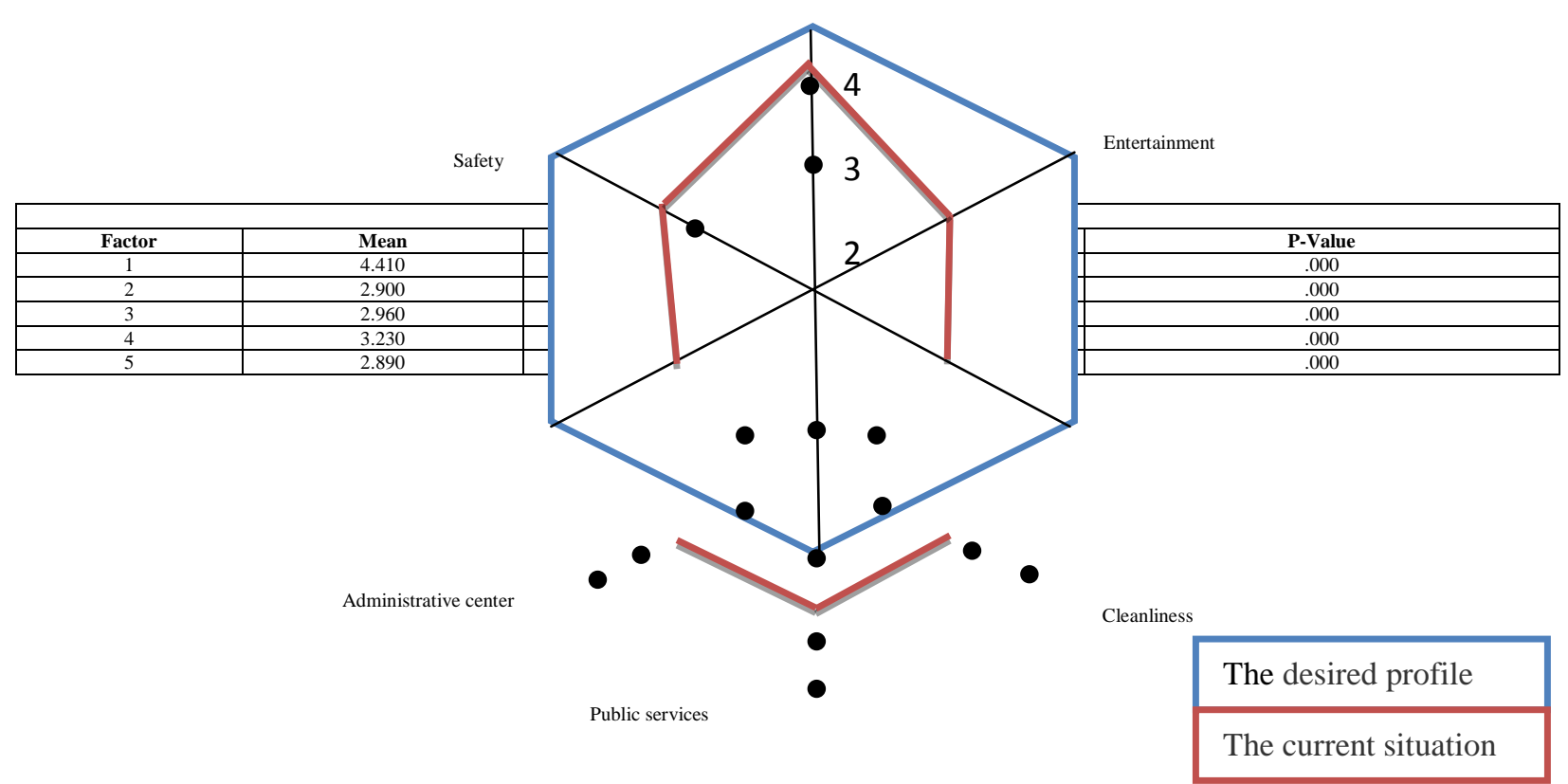

Figure (8) satisfaction mean with the different factors of social aspect 
Table 14 Social Aspect for each factor

Part IV-A- Technical aspect.

\begin{tabular}{|c|c|c|c|c|}
\hline \multicolumn{7}{|c|}{ Table 15 Technical Aspect for each factor (N = 90) } \\
\hline Factor & Mean & Median & S. & P-Value \\
\hline 1 & 3.18 & 3.000 & 1.137 & .000 \\
\hline 2 & 3.08 & 3.000 & 0.997 & .000 \\
\hline 3 & 3.11 & 3.000 & 0.988 & .000 \\
\hline 4 & 3.03 & 3.000 & 0.893 & .000 \\
\hline 5 & 3.02 & 3.000 & 0.924 & .000 \\
\hline 6 & 3.11 & 3.000 & 0.917 & .000 \\
\hline 7 & 3.07 & 3.000 & 0.897 & .000 \\
\hline 8 & 3.03 & 3.000 & 0.905 & .000 \\
\hline 10 & 3.00 & 3.000 & 0.912 & .000 \\
\hline 11 & 2.97 & 3.000 & 0.942 & .000 \\
\hline 12 & 2.97 & 3.000 & 0.930 & .000 \\
\hline 13 & 2.91 & 3.000 & 0.920 & .000 \\
\hline 14 & 2.84 & 3.000 & 0.886 & .000 \\
\hline 15 & 2.64 & 3.000 & 1.105 & .000 \\
\hline 16 & 2.86 & 0.868 & .000 \\
\hline 17 & 2.81 & 3.000 & 0.970 & .000 \\
\hline 18 & 2.83 & 3.000 & 1.019 & .000 \\
\hline 19 & 2.80 & 3.000 & 0.902 & .000 \\
\hline
\end{tabular}

Out of inspection table, these two bellow chosen as exemplars out of many various important factors:

- Factor 1 (Internal paintings): this factor discussing the amount of satisfaction of internal painting type and color of the residents houses. The mean was 3.180 whereas the median 3.000, meaning that the respondents satisfied with the colors and that there were no dissatisfaction in this regard.

- Factor 2 (Quality of furniture): the quality of furniture and carpets are important for houses. The mean was 3.08 and median 3.000, hence, the respondents agree that the furniture quality is good enough, but $60 \%$ of respondents believe that it was not as they expected. Moreover, $40 \%$ of respondents requested to change the carpets that provided.

Table 16 bellow shows the technical aspect for each factor of all the 19 factors, whereas; table 16 shows the technical aspect in "Yes" and "No" Questions form).

Part IV-B- Technical aspect

Table 15 Technical Aspect for each factor

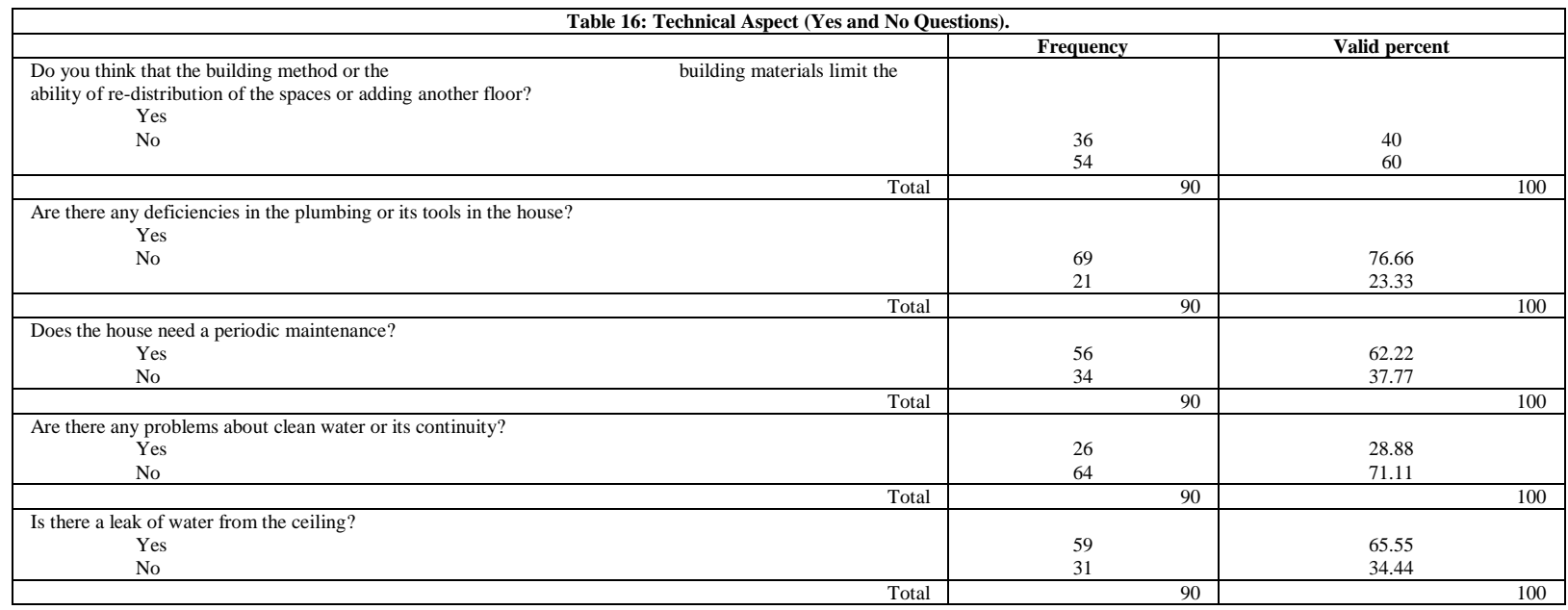

Based on the statistical data, out of $60 \%$ of the respondents do not think that the building design, the building construction and the building services limit the ability of re-distribution of the spaces or adding another floor. While $76.66 \%$ pointed out that, there are deficiencies in the plumbing or its provisions in the house. Taking into consideration the periodic maintenance of the house, $62.22 \%$ said that the there is an urgent need for it. However, $71.11 \%$ mentioned that there are no any problems about clean water supply or its continuity. Majority of the respondents $65.55 \%$ answered that there is no ceiling water leakage.

Table 17: Technical Aspect Statistics

\begin{tabular}{|l|c|c|c|c|}
\hline \multicolumn{5}{|c|}{ Table 17: Technical Aspect Statistics. (N = 90) } \\
\hline & Mean & Median & S.D & P-Value \\
\hline Technical Aspect & 2.951 & 3.000 & 0.138 & .000 \\
\hline
\end{tabular}


Table (17) provides that the respondents are not satisfied enough with the technical services provided into the residents (mean 2.951), the P-Value was less than 0.050 (.000). Hence, the hypothesis that the residents are satisfied with the technical environment provided not agreed with. Table (18) bellow shows the three most liked and three most disliked of the respondents about buildings.

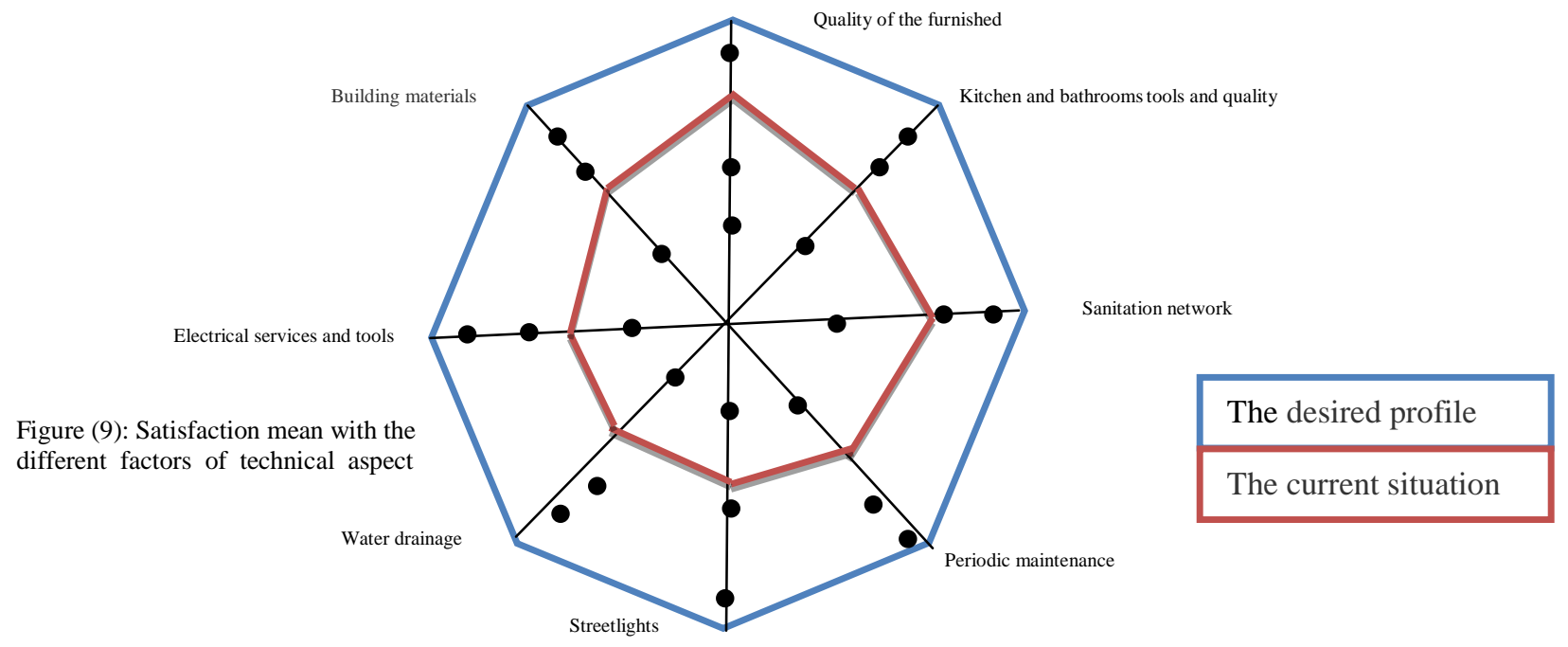

Table 18: the three most liked and three most disliked of the respondents about buildings

\begin{tabular}{|l|c|c|}
\hline \multicolumn{2}{|c|}{ Table 18: 3 most liked and 3 most disliked of the respondents about building } \\
\hline Most liked & Frequency & Valid percent \\
\hline $1 . \quad$ The standard prototype design & 24 & 38.71 \\
\hline $2 . \quad$ Lighting & 21 & 33.87 \\
\hline $3 . \quad$ Accessibility to social services & 17 & 27 \\
\hline Total & 62 & 100 \\
\hline Most Disliked & & \\
\hline $1 . \quad$ Space between neighbors & 33 & \\
\hline 2. Water drainage & 6 & 76.74 \\
\hline $3 . \quad$ Pavements & 4 & 13.95 \\
\hline Total & 43 & 9.30 \\
\hline
\end{tabular}

Based on the result of the survey, these are both likes and most dislikes of the respondents about the residential complex. Among the 90 respondents, 62 have listed the same which broken down as follow: 24 (38.71\%) for the standard prototype design, 21 (33.87\%) for the lighting, and $17(27.42 \%)$ for the accessibility to social services. From the 62 respondents, $38.71 \%$ of them have answered the standard prototype design. Likewise, the space between neighbors listed as the most disliked of the residents with $76.74 \%$ from 43 respondents.

Do you want the result of the survey sent to you? Table (19) shows that 69 respondents want the results of the survey sent to them.

Table 19 shows that 69 respondents want the results of the survey sent to them

\begin{tabular}{|c|c|c|c|}
\hline \multicolumn{4}{|c|}{ Table 19: Survey Feedback } \\
\hline & & Frequency & Valid Percent \\
\hline 76.7 & Yes & 69 & \\
\hline 23.3 & No & 21 & \\
\hline 100.0 & Total & 90 & \\
\hline
\end{tabular}

Low-income housing in Saudi Arabia represents a point of anchorage and home base in pointing towards a favored way of appropriate space and residence. Respondent's opinion was reflective of being an overall assessment of the given housing situations. A number of issues require consideration while evaluating post occupancy perceptions of low-income housing in Saudi Arabia. Houses provided by government agencies and private developers but the buyers did not have many options to choose from because the houses had almost the same construction procedures, layout and materials although the orientation varied to some extent. The house owners belong to almost the same cultural backgrounds, especially in view of the house categorization being of low income. However, there was uniformity in regards to the fact that all owners were Muslims. This Chapter provides a discussion for the findings of this study. 


\section{6-1 The Functional aspect of the building.}

Knowing that a number of residents shouldered themselves the responsibility to change the designs of their houses altering the front. Many built reception rooms for guests and transformed the yard into living rooms. In the research, majority of respondents were not satisfied with the house areas and spaces. The overall quality of the houses did not appeal to them although they appeared to be contented with the size of the central yard. In particular, most respondents (90\%) were not happy with the area of the house; however about $50 \%$ were satisfied with the internal yard, and about $56 \%$ with external backyard. Moreover, respondents $(64 \%)$ were not satisfied with the size of the living room, although they were satisfied with the number of rooms in the house. In other words, they believed that the number of rooms in the house is enough for their life requirements, but they consider the living room small compared to the house size.

Ventilation is one of the basic requirements of a good house, Ubaid, D. (2009). The majority of respondents (70\%) were satisfied with the living rooms, where different recreational activities of the family take place such as watching $\mathrm{TV}$, listening to music, enjoying games and entertaining guests and friends, or even studying. Therefore, a good ventilation system is an important issue regained through big or well-placed windows and doors in order to let the air circulate inside the living room, Hasija, A. (2010).

There is no well-managed landscape, which is an indication to low quality of external environment, Oail, M. (2011). Opinions expressed by respondents that there were lack of liveliness and privacy in the houses. Regarding external spaces, respondents $(70 \%)$ felt that there were not appropriate storage areas. Therefore, they consume the external spaces provided for storage areas, or external guest and living rooms, which financially supported by their own pockets.

\section{6-2 The Social aspect of the building.}

In the Islamic culture, there is segregation in terms of gender, specifically in regards to the house social life activities. The residential complex designers did provide separate reception areas for women, which assumed to be at the end of the house, close to the master bedrooms. This creates inconvenience for males when already present in the house. A further issue is the means of provision of privacy that is possible only if the doors and windows are closed and curtains drawn.

The social aspect of a building is important for homeowners or residents because it helps in their interaction with neighbors, relatives, visitors, and family members. Good social relations found to contribute in the quality of life for people of various races, Oak, M. (2011). The respondents contributed in the survey clearly revealed that Arabic culture of social life on which social activities based in the housing complex much neglected. In the research, respondents were not appearing to be satisfied (82\%) with entertainment areas such as parks and playing zones for children. Further, they are also not contented with the quality of public services such as hospitals, schools and mosques. Many respondents attested that administrative services in the housing complex were not enough and public maintenance not in order as well, therefore, need to be rectified.

\section{6-3 The Technical aspect of the building.}

Government need to allocate large tracts of land for developing housing projects along with minimum levels of infrastructure Preiser, W.F.E. et al (1988).. In Saudi Arabia, low-income houses provided at the periphery of cities, but there are insufficient transport facilities to take care of such suburban expansions. This aspect needs rectification because the horizontal sprawl will continue as more as more housing projects developed in suburbs. Most significantly, Government must realize that there is a positive criteria for its massive funding for larger numbers of affordable home ownership, but the infrastructure and structural issues in low income housing areas have to be resolved not only through state spending but also through public private partnerships.

Respondents in the survey were satisfied (36\%) about color used to paint the houses as also about the quality of furniture (29\%). However, about $40 \%$ said that the quality of carpets provided not good, therefore, need replacement. In general, residents were not happy with the quality of the residential complex; hence, the quality according to them needs improvement by the government. The sanitation networks not considered proper by most respondents (70\%) as well as for electricity networks. The standard of electricity fittings are not of good quality that is why many house owners replaced them. Thus, respondents feel that periodic maintenance of the complex is very important so that the quality remains at high standard; however, the research found that about $73 \%$ were not satisfied with the periodic maintenance that provided in the complex. Respondents (87\%) informed that there is lack of adequate spaces and sewerage provisions for ablution in the complex mosque, and commented that workers responsible for maintenance of electricity services are not doing their work properly since lots of work consider as their responsibility were left undone.

7.1 Conclusions 
In Saudi Arabia, the high price of land prevents many families to afford land to build their homes. Development plans consider raising the standard of living and improving the quality of life for citizens as a priority shouldered by the Ministry of Planning and Economy in KSA, 2011. Thus, the Saudi government had built some projects for lowincome citizens looking for home or do not have one and cannot afford to buy a land or rent a home. In this research that adopted Al-Ghazalah development housing Complex as a population of the study, found that there was positive indication of the use of POEs for low-income housing units in Saudi Arabia. In particular, indicated that there was somehow an acceptable satisfaction experienced by the residents of the Hail housing Complex. In other words, for the three aspects investigated the mean was at the range of three (neutral). However, results may not encompass a total experience of all residents but indicative of a reasonable sample population of 90 respondents out of 250 units. Nonetheless, the less than average reception of the POE meant that there remains an adamant behavior on the part of the majority of residents about providing their opinions to the government. Specifically, many of Saudi Arabians are still conservative about spreading their opinions out on matters that regard the government or its projects. Overall, although the project designed for the low-income earners, providing acceptable quality standard but affordable housing units that meet the basic human needs as well as expectations of users definitely helped improve the personal and socio-economic experience of the residents. As indicated on the detailed results, there are some technical and social aspects that some residents want their urgent improvement. For instance, spaces inside the house, design of more movable walls or partitions to allow occupants a chance to rearrange or redesign the interiors of their houses and versatility of spaces made respondents request building floor plans compatible with Islamic values, customs and traditions as well as possible renovations or expansions. While addressing future or even current needs of residents may be the main goal of planners, it is always important to consider sustainability and 'livability' of spaces that inspire growth as well as forthcoming issues pertaining to energy, space and resources use, residents' need and want, as well as social impacts.

\subsection{Recommendations}

In this research, respondents of the Al-Ghazalah development housing Complex of Hail were not satisfied enough with the home units provided. Thus, urgent maintenance must take place for more conducive living conditions in the housing complex of low-income citizens. Moreover, units that constructed in this complex had one prototype model of home design as all the 250 units had the same design. The units as well have the same number of rooms without taking into consideration the number of members for each family; thus, whether there are more than one model that might have helped the low-income citizens to have a good variety of options or not, issues regarding periodical maintenance require serious and urgent attention. However, the various POEs undertaken on the future residential complexes besides Al-Ghazalah development housing Complex of Hail will surely provide a clearer result and understanding to the experiences of residents and owners of such buildings.

\section{REFERENCES}

1. Abdullah, A. (2009). The need for housing in the Hail Region: King Fahd National Library for publication.

2. Astnpola, A. (1995). The impact of social and economic problems in the balance of family. King Saud University.

3. Abdall, K. (2009). The need for housing in Riyadh Saudi Arabia for Studies and Research.

4. Al-Harigi, F. (2004). Housing in the Kingdom of Saudi Arabia: Assessment of Demand by Regions. King Faisal University Press.

5. $\quad$ Bryman, A. (2008). Social Research Methods. 3rd ed. Oxford: Oxford University Press.

6. Bahmam, A. \& Bahbayl, M. (2007).An analytical study for the design of housing units in charitable housing projects in Saudi Arabia.

7. Bordass, B. (2003). Learning more from our buildings or just forgetting less? Building Research \& Information, 31(5).

8. Bordass, B. \&Leamon, A. (2005).Making feedback and post-occupancy evaluation routine 1: A portfolio of feedback techniques. Building Research \& Information, Number 33(4).

9. British Council for Offices (2007).Guide to Post Occupancy Evaluation, document available at http://www.bco.org.uk/research/researchreports/detail.cfm?rid=99.

10. Baird, G. (2001). Post-occupancy evaluation and probe: A New Zealand Perspective. Building Research \& Information, 29 (6), pp. 469-472.

11. Bachman, Leonard R. (2008). 'Architecture and the Four Encounters with Complexity', Architectural Engineering and Design Management, Vo. 4, no. 1. 
12. Bordass Leaman \&Ruyssevelt (2001).Assessing building performance in use 5: conclusions and implications. Building Research \& Information, Number 29(2).

13. Brown, Stephen A 2001, Communication in the Design Process, Spon Press, London.

14. Bakhtiar L (1994) Ramadan: Motivating Believers to Action: An Interfaith Perspective. Chicago: Kazi Publications Inc.

15. Central Intelligence Agency. (2011) The World Fact book: Saudi Arabia. Available at: https://www.cia.gov/library/publications/the-world-factbook/geos/sa.html

16. Fahad, A. (1982).This is our country: Glimpses of Hail, Riyadh: King Saud University Press.

17. Federal Facilities Council (2002). Learning from our Buildings: A State-of-the-Practice Summary of PostOccupancy Evaluation, National Academy Press, Washington, D.C., Technical Report No. 145.

18. Gray, D. G. (2000).Resident participation in HUD affordable housing preservation projects: What works? Davis, California: University of the Centre for Cooperatives.

19. Gandil, M. M. (1996). the Impact of Dwelling Quality and Neighborhood Quality on the Estimation of the Income Elasticity of Demand for Rental Housing in Jeddah, Saudi Arabia. Urban Studies 33 (2).

20. Gandil, M. M. (1996) The Kingdom of Saudi Arabia, 2nd edn. Gainesville, FL: The University Press of Florida.

21. Hasija, A. (2010), Living room. Document available at http://www.gharexpert.com/category/1522/Doors-Windows-0.aspx ?PL $=2 \&$ Estimator $=$.

22. Khaleej Times (2009). Saudi Arabia on Low-cost Housing, Khaleej Times [Online], document available at: http://web.ebscohost.com/ehost/detail?vid=4\&hid=11\&sid=848f8491-6ab1-4cf6-

96f6372c696e1058\%40sessionmgr15\&bdata=JnNpdGU9ZWhvc3QtbGl2ZQ\%3d\%3d\#db=nfh\&AN=2W62 W63525225755.

23. Leung, C. C. (2005).Resident Participation: A Community-Building Strategy in Low-Income Neighborhoods. Joint Center for Housing Studies of Harvard University.

24. Oail, M. (2011).Land prices in the Kingdom of Saudi Arabia, Al-Watan, Saudi Arabia.

25. Oak, M. (2011). List of Different Recreational Activities, document available at http://www.buzzle.com/articles/list-of-different-recreational-activities.html

26. Preiser, W. F. E. et al (1995). Post-Occupancy Evaluation: How To Make Buildings Work Better.Facilities, 13 (11).

27. Preiser, W.F.E. et al (2001). Feedback, feed forward and control: post-occupancy evaluation to the rescue. Building Research \& Information, 29(6).

28. Preiser, W.F.E. et al (1988).Post-occupancy evaluation. New York: Van Nostrand Reinhold.

29. Presidency of Meteorology and Environment (2011), General information about the Kingdom of Saudi Arabia Riyadh [Online], Available at: http://www.pme.gov.sa/

30. Robinson, Charles W, (2005). 'Post-Occupancy Evaluation', Library Administrator's Digest, Vo. 40, no. 3.

31. Ubaid, D. (2009). Good Ventilation a Basic Requirement of a Good House, document available at http://ezinearticles.com/?expert=Dogarsahab_Ubaid.

32. Watson, M. et al (2001). Low-Cost Housing in Barbados: Evolution or Social Revolution? University of the West Indies Press: Barbados, Jamaica, Trinidad and Tobago.90 